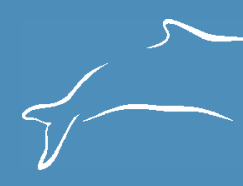

\begin{tabular}{|c|c|}
\hline \multicolumn{2}{|c|}{ Article Info } \\
\hline Manuscript type & Article \\
\hline \multicolumn{2}{|l|}{ Article history } \\
\hline Received & 30 January 2013 \\
\hline Received in revised form & 24 September 2013 \\
\hline Accepted & 24 October 2014 \\
\hline Available online & 17 August 2015 \\
\hline \multicolumn{2}{|c|}{$\begin{array}{l}\text { Keywords: skin diseases, calf mortality, Delphinidae, nearshore } \\
\text { waters, South America, epidemiology }\end{array}$} \\
\hline \multicolumn{2}{|c|}{ Responsible Editor: Nataly Castelblanco-Martínez } \\
\hline $\begin{array}{l}\text { Citation: Van Bressem M- } \\
\text { M., Santos, M., Viddi, F., } \\
\text { K. (2015) Epidemiologica } \\
\text { cetaceans from South Ame } \\
\text { Aquatic Mammals 10(1): } \\
\text { http://dx.doi.org/10.5597 }\end{array}$ & $\begin{array}{l}\text { Flach, L., Reyes, J.C., Echegaray, } \\
\text { ix, F., Lodi, L. and Van Waerebeek, } \\
\text { aracteristics of skin disorders in } \\
\text { an waters. Latin American Journal of } \\
32 . \\
\text { jam00190 }\end{array}$ \\
\hline
\end{tabular}

\title{
Epidemiological characteristics of skin disorders in cetaceans from South American waters
}

\section{Marie-Françoise Van Bressem ${ }^{\dagger,}$, Leonardo Flach $^{\ddagger}$, Julio César Reyes $\$$, Mónica Echegaray Marcos Santos ${ }^{5}$, Francisco Viddi ${ }^{\#}$, Fernando Félix ${ }^{\varsigma}$, Liliane Lodi ${ }^{\&}$ and Koen Van Waerebeek ${ }^{\dagger}$}

\author{
${ }^{\dagger}$ Cetacean Conservation Medicine Group (CMED), Centro Peruano de \\ Estudios Cetológicos (CEPEC), Museo de Delfines, Pucusana, Lima 20, Peru \\ ‡Instituto Boto Cinza, Rua Gastão de Carvalho L2 Q4, Itacuruçá- \\ Mangaratiba, RJ Brazil. \\ ${ }^{5}$ Áreas Costeras y Recursos Marinos (ACOREMA), Calle San Francisco 253, \\ 201-B, Pisco, Peru \\ 'Laboratório de Biologia da Conservação de Mamíferos Aquáticos, Instituto \\ Oceanográfico, Universidade de São Paulo, Praça do Oceanográfico, 191, sala \\ 145-A, Butantã, 05508-120 São Paulo, SP, Brazil \\ "Instituto de Ciencias Marinas y Limnologicas, Universidad Austral de Chile \\ and Centro Ballena Azul, clo Instituto de Ecología y Evolución, Universidad \\ Austral de Chile, Avenida Eduardo Morales Miranda, Campus Isla Teja, \\ 14101Valdivia, Chile \\ ${ }^{s}$ Museo de Ballenas, Av. General Enríquez Gallo entre calles 47 y 50, 241550 \\ Salinas, Ecuador \\ \&Projeto Golfinho-Flíper, Instituto Aqualie, Avenida Dr. Rua Paulo Japiassu \\ Coelho 714, sala 206, 36033-310 Juiz de Fora, MJ, Brazil \\ * Corresponding author, email: mfb.cmed@gmail.com
}

Abstract. We document the macroscopic phenotypic characteristics (relative size, location, pattern, colour, extension), prevalence and evolution of five types of skin disorders of unknown aetiology, including 'green-brown plaques' (GBP), 'orange patches' (OPA), 'cutaneous nodules' (NOD), 'pale dermatitis' (PAD) and 'expansive annular lesions' (EAL) in five odontocete species ( $\mathrm{n}=559$ individuals) from the Southeast Pacific $(\mathrm{n}=230)$ and Southwest Atlantic $(\mathrm{n}=329)$ Oceans. GBP affected two likely-adult Sotalia guianensis traveling side-by-side in a freshwater area of the Cananéia Estuary in August 2009. Low salinity is suggested as predisposing factor. OPA were distinguished in three of 209 (1.4\%) free-ranging S. guianensis in Sepetiba Bay, Brazil, during winter months of 2005-2008. Epibiont diatoms are suspected aetiological agents. NOD were chronically present in one male adult Orcinus orca observed off the coast of southern Brazil in 20072010. PAD was seen in free-ranging individuals and carcasses of Tursiops truncatus, S. guianensis and Pseudorca crassidens from both the Atlantic and Pacific Oceans in 1992 and in 2004-2009. Prevalence was 1\% in 103 S. guianensis from Paranaguá Estuary (Brazil), 2.3\% in 222 S. guianensis from Sepetiba Bay and 6.9\% in 87 inshore T. truncatus from Paracas Bay, Peru. Although in some cases the lesions covered up to $35-40 \%$ of the visible body surface and ulcers may occur there was no evidence of mortality and, in time-series of six individuals, PAD eventually healed. In six T. truncatus and five $S$. guianensis acutely affected, PAD was associated with minor cutaneous injuries and scars, including tooth rakes, suggesting infection routes for opportunistic pathogens. EAL were noted in a Cephalorhynchus eutropia calf from Palena province, Chile, in 2003 and in a P. crassidens calf washed ashore dead in southern Brazil in 2009. The C. eutropia calf disappeared, and probably died, two weeks after first observation. Prevalence of EAL was 6.7\% in 15 C. eutropia in 2002-2004. These data suggest that EAL are potentially lethal in calves. PAD and EAL were primarily seen in cetaceans inhabiting biologically or chemically contaminated nearshore waters. In view of their emergence and occasional severity these disorders should be the subject of systematic monitoring. 


\section{Resumo}

Documentamos as características fenotípicas macroscópicas (anátomo-patologia, localização, padrão, cor e extensão), prevalência e evolução de cinco tipos de condiçôes cutâneas de etiologias desconhecidas, incluindo 'placas marromesverdeadas' (PME), 'manchas alaranjadas' (MAL), 'nódulos cutâneos' (NOD), 'dermatite pálida' (DEP) e 'lesôes anulares expansivas' (LAE) em cinco espécies de odontocetos ( $\mathrm{n}=559$ indivíduos) do sudeste do Pacífico $(\mathrm{n}=230)$ e sudoeste do Atlântico ( $\mathrm{n}=329)$. PME afetaram dois prováveis indivíduos adultos de Sotalia guianensis que deslocavamse em paralelo em uma área de água doce do Estuário de Cananéia em agosto de 2009, sendo a baixa salinidade sugerida como um fator predisponente. MAL foram observadas em três de 209 (1,4\%) S. guianensis na Baía de Sepetiba, Brasil, durante os meses de inverno de 2005-2008; diatomáceas epibiontes são os agentes etiológicos suspeitos. NOD estavam cronicamente presentes em um macho adulto de Orcinus orca observado na costa sul e sudeste do Brasil em 20072010. DEP foi vista em indivíduos de vida livre e carcaças de Tursiops truncatus, S. guianensis e Pseudorca crassidens no Atlântico e Pacífico em 1992 e em 2004-2009. A prevalência foi de 1\% em 103 S. guianensis do Estuário de Paranaguá (Brasil), 2,3\% em 222 S. guianensis na Baía de Sepetiba e 6,9\% em 87 T. truncatus costeiros da Baía de Paracas, Peru. Embora em alguns casos as lesões cobrissem até 35-40\% da superfície corporal visível, e úlceras possam ter ocorrido, não houveram evidências de mortalidade e, em uma série temporal de seis indivíduos, a DEP eventualmente cicatrizou. Em seis T. truncatus e cinco S. guianensis afetados de forma aguda, a DEP foi associada com injúrias cutâneas menores e cicatrizes, incluindo marcas de dentes, sugerindo rotas de infecção por patógenos oportunistas. LAE foram notadas em um filhote de Cephalorhynchus eutropia da Província de Palena, Chile, em 2003 e em um filhote de P. crassidens encalhada morta no sul do Brasil em 2009. O filhote de C. eutropia desapareceu, e provavelmente morreu, duas semanas após a primeira observação. A prevalência de lesóes anulares expansivas foi de $6,7 \% \mathrm{em} 15$ C. eutropia em 2002-2004. Esses dados sugerem que LAE são potencialmente letais em filhotes. DEP e LAE são vistas primariamente em cetáceos que habitam águas costeiras contaminadas, biológica ou quimicamente. Em face de sua emergência e ocasional severidade, essas condições devem ser objetos de monitoramentos sistemáticos.

\section{Introduction}

About $75 \%$ of the $c a .88$ recognized cetacean species of the world inhabit the marine and freshwater biotopes of South America. There, as in other continents, they face a number of anthropogenic threats, primarily high mortality in fisheries and severe environmental degradation. Several species, populations and communities are considered vulnerable or endangered (Culik, 2004). Especially for the latter, any source of enhanced mortality and reduction in fecundity is of concern. Increasingly documented in South American cetaceans, infectious diseases have the potential to negatively impact population abundance by elevating baseline mortality rate (e.g. morbillivirus disease, Crassicauda spp. infestation) or by negatively affecting reproduction (e.g. brucellosis and genital papillomavirosis) (Van Bressem et al., 2007; 2009a). Some emerging cutaneous disorders may also lead to increased mortality. Three of these conditions (tattoo skin disease-TSD, lobomycosis and lobomycosis-like disease-LLD) are well-documented in South American odontocetes ${ }^{1}$ (de Vries and Laarman, 1973; SimóesLopes et al., 1993; Van Bressem et al., 1993; 2007; 2009a, $b$; Daura-Jorge and Simóes-Lopes, 2011). TSD is caused

${ }^{1}$ Moreno, I.B., Ott, P.H., Tavares, M., Oliveira, L.R., Borba, M.R., Driemeier, D., Nakashima, S.B., Heinzelmann, L.S., Siciliano, S. and Van Bressem, M-F. (2008) Mycotic dermatitis in common bottlenose dolphins (Tursiops truncatus) from southern Brazil, with a confirmed record of lobomycosis disease. Paper SC/60/DW1 presented to the IWC Scientific Committee, May 2008, Santiago, Chile.

Available at http://iwc.int/index.php?cID=1790\&cType=document by poxviruses and diagnosable from irregular, grey, black or yellowish, stippled cutaneous lesions. It affects Delphinidae and Phocoenidae from Peru, Ecuador, Chile and Brazil. Prevalence levels varied between 3.5\% (short-beaked common dolphin Delphinus delphis, Ecuador) and 62.3\% (Burmeister's porpoise Phocoena spinipinnis, Peru) in 1992-2008 (Van Bressem et al., 2007; 2009b). Generally, juveniles had a higher probability of suffering TSD than adults, presumably because adults had acquired active immunity following infection (Van Bressem et al., 2009b). When endemic, TSD does not appear to induce a high mortality rate. However, it may kill neonates and calves without protective immunity (Van Bressem et al., 1999; 2003). Characterized by greyish, whitish to slightly pink, verrucous lesions, often in pronounced relief, that may ulcerate and form plaques, lobomycosis ${ }^{2}$ and LLD naturally affect common bottlenose dolphins Tursiops truncatus and Guiana dolphins Sotalia guianensis from Brazil, Ecuador, Peru, Colombia, Venezuela and Suriname (de Vries and Laarman, 1973; Simốes-Lopes et al., 1993; Van Bressem et al., 2007; Bermudez et al., 2009; Daura-Jorge and Simóes-Lopes, 2011). Lobomycosis is caused by a dimorphic fungus resembling Lacazia loboi (Taborda et al., 1999; Hauboldt et al., 2000) but genetically more closely related to Paracoccidioides brasiliensis (order Onygenales, family Ajellomycetaceae) (Rotstein et al., 2009; Esperon et al., 2011; Ueda et al., 2013). LLD is

${ }^{2}$ Sometimes referred to as lacaziosis. 
Table 1. Prevalence of four types of skin disorders in cetaceans from South America. Abbreviations are: $\mathrm{N}=$ total number of specimens examined, Prev= prevalence, $\mathrm{FR}=$ free-ranging, $\mathrm{BC}=$ by-catch, $\mathrm{ST}=$ stranded, $\mathrm{GBP}=$ green-brown plaques, $\mathrm{OPA}=$ orange patches, $\mathrm{PAD}=$ pale dermatitis, $\mathrm{EAL}=$ expansive annular lesions.

\begin{tabular}{|c|c|c|c|c|c|c|c|c|c|c|}
\hline $\begin{array}{l}\text { Country } \& \\
\text { species }\end{array}$ & Habitat & Region & $\begin{array}{l}\text { Ocean } \\
\text { province }\end{array}$ & $\begin{array}{l}\text { Sampling } \\
\text { period }\end{array}$ & Specimens & $\mathbf{N}$ & $\begin{array}{l}\text { GBP } \\
\text { Prev }\end{array}$ & $\begin{array}{l}\text { OPA } \\
\text { Prev }\end{array}$ & $\begin{array}{l}\text { PAD } \\
\text { Prev }\end{array}$ & $\begin{array}{l}\text { EAL } \\
\text { Prev }\end{array}$ \\
\hline \multicolumn{11}{|l|}{ Brazil } \\
\hline Sotalia guianensis & Inshore/estuarine & Sepetiba Bay & SW Atlantic & $2005-2008$ & $\mathrm{BC}$ & 10 & $0 \%$ & $0 \%$ & $20 \%$ & $0 \%$ \\
\hline Sotalia guianensis & Inshore/estuarine & Sepetiba Bay & SW Atlantic & $2005-2008$ & FR & 209 & $0 \%$ & $1.4 \%$ & $1.4 \%$ & $0 \%$ \\
\hline Sotalia guianensis & Inshore/estuarine & Sepetiba Bay & SW Atlantic & $2005-2008$ & ST & 3 & $0 \%$ & $0 \%$ & $0 \%$ & $0 \%$ \\
\hline Sotalia guianensis & Inshore/estuarine & Paranaguá Estuary & SW Atlantic & $2006-2008$ & FR & 103 & $0 \%$ & $0 \%$ & $1 \%$ & $0 \%$ \\
\hline Sotalia guianensis & Inshore/estuarine & Cananéia Estuary & SW Atlantic & 2009 & FR & 2 & $100 \%$ & $0 \%$ & $0 \%$ & $0 \%$ \\
\hline \multicolumn{11}{|l|}{ Ecuador } \\
\hline Pseudorca crassidens & Oceanic & Santa Elena Peninsula & SE Pacific & 1992 & ST & 28 & Unk & Unk & $3.6 \%$ & Unk \\
\hline \multicolumn{11}{|l|}{ Chile } \\
\hline $\begin{array}{l}\text { Cephalorhynchus } \\
\text { eutropia }\end{array}$ & Inshore/estuarine & Pumalin & SE Pacific & $2002-2004$ & FR & 15 & $0 \%$ & $0 \%$ & $0 \%$ & $6.7 \%$ \\
\hline \multicolumn{11}{|l|}{ Peru } \\
\hline Tursiops truncatus & Inshore/estuarine & central Peru & SE Pacific & 1993-1994 & $\mathrm{BC}$ & 19 & $0 \%$ & $0 \%$ & $0 \%$ & $0 \%$ \\
\hline Tursiops truncatus & Oceanic & central Peru & SE Pacific & $1985-1995$ & $\mathrm{BC}$ & 65 & $0 \%$ & $0 \%$ & $0 \%$ & $0 \%$ \\
\hline Tursiops truncatus & Inshore/estuarine & Paracas Bay & SE Pacific & 2004-2009 & FR & 87 & $0 \%$ & $0 \%$ & $6.9 \%$ & $0 \%$ \\
\hline Tursiops truncatus & Inshore/estuarine & Supay-La Mina & SE Pacific & 2004-2006 & FR & 15 & $0 \%$ & $0 \%$ & $0 \%$ & $0 \%$ \\
\hline
\end{tabular}

highly reminiscent of lobomycosis but its aetiology is unknown (Van Bressem et al., 2007). Prevalence of the disorders varied from 1.6\% (Gulf of Guayaquil, Ecuador) to 20\% (Tramandaí Estuary, Brazil) in 1990-20091 (Van Bressem et al., 2007; Daura-Jorge and Simóes-Lopes, 2011). At least eight inshore T. truncatus with advanced lobomycosis or LLD died or disappeared in Brazil and Venezuela in 1990-2009 ${ }^{1}$ (SimôesLopes et al., 1993; Bermudez et al., 2009; Daura-Jorge and Simóes-Lopes, 2011). Impairment in adaptive immunity, possibly related to chronic exposure to pollutants, may play a role in the pathogenesis of lobomycosis (Reif et al., 2009).

Over the past decade five other types of formerly unobserved skin disorders, here referred to as 'green-brown plaques' (GBP), 'orange patches' (OPA), 'cutaneous nodules' (NOD), 'pale dermatitis' (PAD) and 'expansive annular lesions' (EAL) have emerged in some odontocete populations on the Pacific and Atlantic coasts of South America ${ }^{3}$ (Van Bressem et al., 2007). These and similar conditions are also increasingly reported worldwide, may be severe and are sometimes associated with

${ }^{3}$ Flach, L., Van Bressem, M-F., Reyes, J.C., Echegaray, M., Siciliano, S., Santos, M., Viddi, F., Crespo, E., Klaich, J., Moreno, I., Tavares, M., Félix, F. and Van Waerebeek, K. (2008) Miscellaneous skin lesions of unknown aetiology in small cetaceans from South America. Paper SC/60/ DW4 presented at the $60^{\text {th }}$ meeting of the Scientific Committee of the International Whaling Commission, Santiago, Chile, 1-13 June 2008. http://iwc.int/index.php?cID=1790\&cType=document the death or disappearance of affected individuals ${ }^{4}$ (Wilson et al., 1997; Riggin and Maldini, 2010; Maldini et al., 2010; Van Bressem et al., 2007; 2013). However, general knowledge of their aetiology, epidemiology, pathogenesis and prognosis is still patchy. In this context, we decided to study their phenotypic and epidemiological characteristics, and to examine their progression and potential impact on odontocete populations from the Southwest Atlantic and Southeast Pacific Oceans.

\section{Material and Methods \\ Sample composition}

The prevalence and macroscopic characteristics of cutaneous conditions were documented in five odontocete species (pooled, $\mathrm{n}=559$ individuals) occurring off Pacific ( $\mathrm{n}$ = 230) and Atlantic ( $\mathrm{n}=329)$ South America, mainly in freeranging individuals $(\mathrm{n}=432)$, but also in stranded cetaceans $(\mathrm{n}=33)$ and in animals killed in fisheries interactions $(\mathrm{n}=94)$ (Table 1). The study covered three types of habitat in tropical to cold-temperate climates: inshore/estuarine (shallow, nearshore waters on the continental shelf, semi-enclosed bays, estuaries and ford entrances), outer neritic (non-inshore shelf waters)

\footnotetext{
${ }^{4}$ Barry, K.P., Gorgone, A.M. and Mase, B. (2008) Lake Pontchartrain, Louisiana Bottlenose Dolphin Survey Summary 28 April 2008-10 May 2008. Southeast Fisheries Science Center, National Marine Fisheries Service, NOAA Protected Resources and Biodiversity Division, PRBD Contribution: PRBD-08/09-01.
} 
and oceanic waters (beyond the shelf edge, depth $>200 \mathrm{~m}$ ) (Table 1). Some data analysed in this study were obtained from a previously published paper on the preliminary identification of skin disorders in odontocetes from South America (Van Bressem et al., 2007).

\section{Free-ranging individuals}

This category comprised photographic material of four delphinid species collected for individual identification purposes (Table 1) during boat and shore-based surveys in 1991-20095, 6 (Reyes et al., 2002; Santos and Netto, 2005; Santos and Rosso, 2007). Individual dolphins were identified through natural marks (Würsig and Jefferson, 1990). Maturity status (calf, juvenile, adult) was estimated from relative body size, behavioral clues, colour pattern and from the verified duration of residence (Wells et al., 1980; Shane, 1990; Santos and Rosso, 2007; 2008; Izodoro and Le Pendu, 2012). A minimum prevalence of skin conditions was estimated for bottlenose dolphins from Paracas Bay, Peru, for Guiana dolphins from Sepetiba Bay and Lagamar Estuary (including the Paranaguá and Cananéia estuaries), Brazil, and for Chilean dolphins Cephalorhynchus eutropia in Reñihue Fjord, Palena province, Chile.

\section{Specimens from strandings and bycatch}

Carcasses of Guiana dolphins from Brazil, false killer whales Pseudorca crassidens from Ecuador and Brazil and bottlenose dolphins from Peru were examined macroscopically for cutaneous diseases, predominantly under field conditions, in 1992-2009 (Table 1). In females, sexual maturity was determined from the presence of at least one corpus luteum or corpus albicans in one of the ovaries, or evidence of lactation or pregnancy. In males, it was ascertained from the presence of seminal fluid in at least one epididymis. When it could not be determined directly, maturity was inferred from body size and mean standard body length at sexual maturation for the populations involved (Van Waerebeek et al., 1990; Félix et al., 1992).

\section{Skin conditions}

For the 26 individuals that scored positive for a skin disorder, macroscopic phenotypic characteristics (relative size, location, pattern, colour, extension) were evaluated from digital photographs by two scientists (MFB, KVW) who exchanged insights in the process towards a consensus view. Only highquality images were utilized. For each free-ranging individual, the affected fraction of the visible dorsal body surface (VBS)

\footnotetext{
${ }^{5}$ Viddi, F.A., Van Bressem, M-F., Bello, M. and Lescrauwaet, A.K. (2005) First records of skin lesions in coastal dolphins off southern Chile. Page 25 in Abstracts, $16^{\text {th }}$ Biennial Conference on the Biology of Marine Mammals, 12 16 December 2005, San Diego, California,USA.

${ }^{6}$ Flach, L. (2006) Photo-identification study reveals human threats towards estuarine dolphins in southeast Brazil. Page 46 in Siciliano, S., Borobia, M., Barros, N.B., Marques, F., Trujillo, F. and Flores, P.A.C. (Eds) Workshop on Research and Conservation of the Genus Sotalia. 19-23 June 2006, Armaçáo dos Búzios, Rio de Janeiro, Brazil.
}

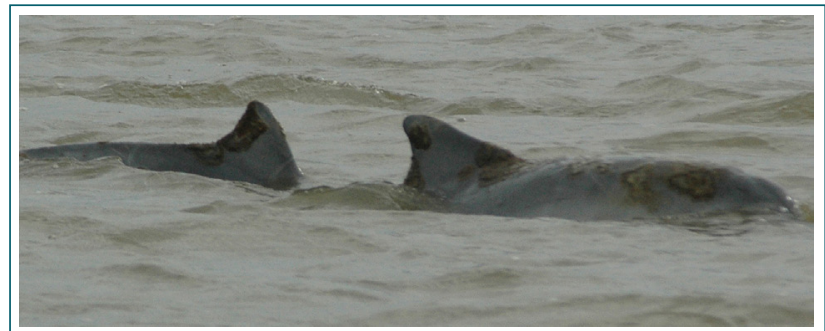

Figure 1. Green-brown plaques in two Guiana dolphins Sotalia guianensis from the Cananéia Estuary on 29 August 2009.

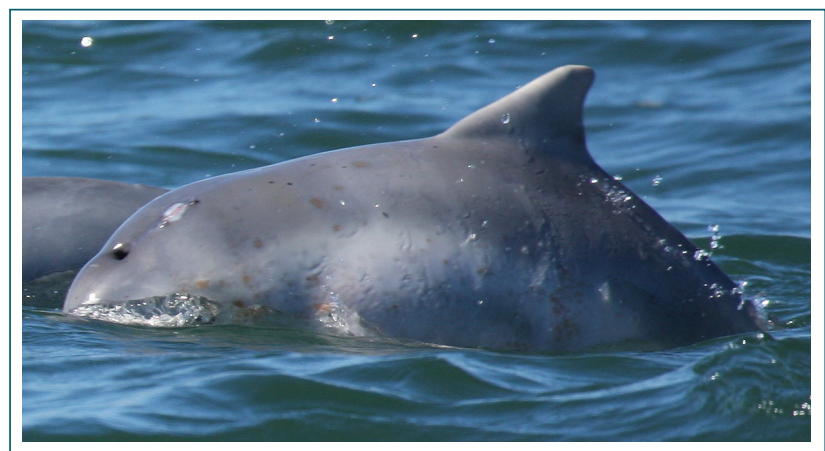

Figure 2. Orange marks and dots in Guiana dolphin calf Sotalia guianensis SEP-43 from Sepetiba Bay on 16 July 2008.

exposed when surfacing was estimated. In dead animals, the affected fraction was evaluated for the entire body surface. Time series allowed an evaluation of relative progress in three bottlenose dolphins, three Guiana dolphins (two from Sepetiba Bay; one from Paranaguá Estuary), one Chilean dolphin and one killer whale Orcinus orca. Five phenotypically distinctive skin conditions of unknown aetiology were recognized as follows:

(1) Green-brown plaques (GBP): circular plaques, greenbrown in colour;

(2) Orange patches (OPA): generally non-raised, orange or rusty-coloured dots, some of which coalesce to form larger blotches;

(3) Cutaneous nodules (NOD): circumscribed skin nodules, grey or normally pigmented;

(4) Pale dermatitis (PAD): a suspected primary infectious or super-infected skin condition characterized by irregular, slightly raised skin sores, pale in colour, either ulcerated or with a smooth velvety aspect;

(5) Expansive annular lesions (EAL): ring-like lesions consisting of a sharply circumscribed light grey outer ring and a paler inner core either of which may or may not be partially obscured by an orange tinge.

The greatest diameter of the lesions was estimated photogrammetrically on the comparative basis of either an estimated dorsal fin height of (i) $230 \mathrm{~mm}$ for Peruvian inshore bottlenose dolphin, Paracas Bay (J. Reyes and M. Echegaray, unpub. data); (ii) $70 \mathrm{~mm}$ in a Chilean dolphin calf, Reñihue 
Table 2. Characteristics of skin disorders in cetaceans from South America. Abbreviations are: Spec. = specimens, $S M=$ sexual maturity, Assoc. $=$ association, $\mathrm{FR}=$ free-ranging, $\mathrm{ST}=$ stranded, $\mathrm{BC}=$ bycatch, $\mathrm{MAT}=$ mature, $\mathrm{U}=$ unknown, $\mathrm{PR}=$ possible remains, NA = data not available, $\mathrm{DF}=$ dorsal fin.

\begin{tabular}{|c|c|c|c|c|c|c|c|c|c|c|c|}
\hline $\begin{array}{l}\text { Disease/ } \\
\text { dolphin }\end{array}$ & Species & Region & Spec. & Sex & SM & Location & $\begin{array}{r}\text { Stage of } \\
\text { disease }\end{array}$ & $\begin{array}{c}\text { Date } \\
\text { first seen }\end{array}$ & $\begin{array}{c}\text { Assoc. } \\
\text { wounds/ } \\
\text { scars }\end{array}$ & $\begin{array}{l}\text { Number } \\
\text { lesions }\end{array}$ & $\begin{array}{l}\text { Relative } \\
\text { size }\end{array}$ \\
\hline \multicolumn{12}{|c|}{ Greenish-brown plaques } \\
\hline CAN 'A' & S. guianensis & Cananéia Estuary, BR & FR & $\mathrm{U}$ & $\mathrm{U}$ & DF, flank, head, back & acute & 27 Aug 2009 & No & $>10$ & medium to large \\
\hline CAN 'B' & S. guianensis & Cananéia Estuary, BR & FR & $\mathrm{U}$ & $\mathrm{U}$ & Head, back, DF & acute & 27 Aug 2009 & No & $>10$ & medium to large \\
\hline \multicolumn{12}{|c|}{ Orange patches } \\
\hline SEP 43 & S. guianensis & Sepetiba Bay, BR & FR & $\mathrm{U}$ & Calf & left flank, back, head & acute & 16 Jul 2008 & No & $>30$ & small to large \\
\hline SEP 22 & S. guianensis & Sepetiba Bay, BR & FR & $\mathrm{U}$ & MAT & left flank & acute & Jun 2007 & No & $>5$ & small to large \\
\hline SEP 022 & S. guianensis & Sepetiba Bay, BR & FR & $\mathrm{U}$ & MAT & back, DF & acute & 7 Jun 2005 & No & $>5$ & small to large \\
\hline \multicolumn{12}{|c|}{ Cutaneous nodules } \\
\hline KW & O. orca & $\begin{array}{c}\text { northern Parana and } \\
\text { Sáo Paulo, BR }\end{array}$ & FR & M & MAT & back, flank & chronic & $\begin{array}{l}\text { Mar 2005- } \\
\text { Jan } 2007\end{array}$ & No & $>10$ & $\begin{array}{c}\text { small } \\
\text { to medium }\end{array}$ \\
\hline \multicolumn{12}{|c|}{ Pale dermatitis } \\
\hline FF-SN & P. crassidens & Sta Elena Peninsula, EC & ST & $\mathrm{U}$ & $\mathrm{U}$ & fluke & acute & 20 Nov 1992 & possibly & 1 & large \\
\hline PBD015 & T. truncatus & Paracas Bay, PE & FR & $\mathrm{U}$ & $\mathrm{U}$ & DF & acute & 10 Nov 2004 & Yes & 1 & large \\
\hline PBD029 & T. truncatus & Paracas Bay, PE & FR & $\mathrm{U}$ & $\mathrm{U}$ & DF & acute & 24 Jul 2004 & Yes & 2 & large \\
\hline PBD030 & T. truncatus & Paracas Bay, PE & FR & $\mathrm{F}$ & MAT & DF & PR & 17 Aug 2005 & Yes & 2 & large \\
\hline PBD041 & T. truncatus & Paracas Bay, PE & FR & $\mathrm{F}$ & MAT & body & acute & 25 Jun 2009 & Yes & $>5$ & large \\
\hline PBD055 & T. truncatus & Paracas Bay, PE & FR & & $\mathrm{U}$ & DF, back & acute & 25 Jul 2006 & Yes & 1 & medium to large \\
\hline PBD060 & T. truncatus & Paracas Bay, PE & FR & $\mathrm{F}$ & MAT & body & acute & $25 \mathrm{Jul} 2006$ & Yes & $>10$ & small to large \\
\hline PBD078 & T. truncatus & Paracas Bay, PE & FR & $\mathrm{M}$ & MAT & DF & $\begin{array}{c}\text { PR and } \\
\text { acute }\end{array}$ & 20 Aug 2008 & Yes & $>3$ & small to large \\
\hline GUA 'S' & S. guianensis & Paranaguá Estuary, BR & FR & $\mathrm{U}$ & MAT & body & PR & Mar 2007 & No & $>10$ & small to large \\
\hline SEP 3 & S. guianensis & Sepetiba Bay, BR & $\mathrm{BC}$ & $\mathrm{M}$ & MAT & beak & acute & 22 Nov 2006 & Yes & 4 & medium to large \\
\hline SEP 17 & S. guianensis & Sepetiba Bay, BR & $\mathrm{BC}$ & & MAT & beak & acute & 24 Jul 2007 & Yes & $>3$ & small to large \\
\hline SEP 33 & S. guianensis & Sepetiba Bay, BR & FR & & MAT & body & acute & $1 \mathrm{Jul} 2005$ & Yes & $>30$ & small to large \\
\hline SEP 41 & S. guianensis & Sepetiba Bay, BR & FR & $\mathrm{U}$ & MAT & body & acute & 28 Oct 2007 & Yes & $>15$ & small to large \\
\hline SEP 23 & S. guianensis & Sepetiba Bay, BR & FR & $\mathrm{U}$ & MAT & DF, back & PR & 14 Jun 2007 & No & $>20$ & small to large \\
\hline SEP 24 & S. guianensis & Sepetiba Bay, BR & FR & $\mathrm{U}$ & MAT & beak & acute & 14 Jun 2007 & Yes & 1 & large \\
\hline SEP 26 & S. guianensis & Sepetiba Bay, BR & FR & $\mathrm{U}$ & MAT & DF, back & $\mathrm{PR}$ & 15 Jan 2007 & No & 7 & small to large \\
\hline SEP 34 & S. guianensis & Sepetiba Bay, BR & FR & $\mathrm{U}$ & MAT & DF, back & PR & 15 Jan 2007 & No & 8 & small to medium \\
\hline SEP 27 & S. guianensis & Sepetiba Bay, BR & FR & $\mathrm{U}$ & MAT & DF, back & PR & 19 Jan 2007 & No & $>10$ & small to large \\
\hline \multicolumn{12}{|c|}{ Expansive annular lesions } \\
\hline Chilean_19 & C. eutropia & Palena province, CL & FR & $\mathrm{U}$ & Calf & body & acute & 11 Feb 2003 & No & 1 to 5 & small to large \\
\hline ES-Pcr & P. crassidens & Rio Grande do Sul, BR & ST & M & Calf & body & acute & 12 Sep 2009 & Yes & $>30$ & small to large \\
\hline
\end{tabular}

$\mathrm{BR}=$ Brazil, $\mathrm{CL}=$ Chile, $\mathrm{EC}=$ Ecuador, $\mathrm{PE}=$ Peru 
Fjord (F. Viddi, unpub. data); (iii) $1420 \mathrm{~mm}$ for a male killer whale, southern Brazil (Durban and Parsons, 2006); or mean dorsal fin height of (iv) $155 \mathrm{~mm}, \mathrm{n}=10$ in Guiana dolphins, Sepetiba Bay (L. Flach, unpub. data), (v) $130 \mathrm{~mm}, \mathrm{n}=30$ in Guiana dolphins, Paranaguá Estuary (M. Santos, unpub. data); or (vi) $2120 \mathrm{~mm}$ standard body length of false killer whale calf, southern Brazil'; or (vii) $860 \mathrm{~mm}$ fluke span for adult false killer whale, Santa Elena (Fish, 1998). The lesions were further classified as small $(<10 \mathrm{~mm})$, medium-sized $(11-20 \mathrm{~mm})$ or large $(>20 \mathrm{~mm})$ on the basis of their greatest relative diameter.

\section{Results}

\section{Green-brown plaques}

Medium-sized to large GBP, some coalescing, some raised, were seen dorsally in two likely-adult Guiana dolphins of unknown sex, traveling side-by-side (Fig. 1), in a turbid-water

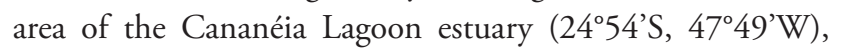
São Paulo State, Brazil, on 27 August 2009. Their behaviour was normal during the $50 \mathrm{~min}$ observation period. Water temperature was $21^{\circ} \mathrm{C}$, depth ranged $2.8-6 \mathrm{~m}$ and salinity was $0 \mathrm{ppm}$. The plaques did not seem associated with other pre-existing traumas and covered $20-30 \%$ of VBS. The dolphins showed no other photo-identifiable natural marks and were not sighted again, impeding evaluation of progress of the condition. Interestingly, GBP were not detected in the Cananéia population during winter (June-July) surveys of the estuary in 2010 with an average water temperature of $18^{\circ} \mathrm{C}$.

\section{Orange patches}

OPA were recognized in three $(1.4 \%, \mathrm{n}=209)$ photoidentified, free-ranging Guiana dolphins in Sepetiba Bay $\left(23^{\circ} 00^{\prime} \mathrm{S}, 43^{\circ} 96^{\prime} \mathrm{W}\right)$, in 2005-2008. Estimated to be twomonths old, calf SEP-43 showed numerous disseminated patches on the left flank (Fig. 2). Two adults had each a minimum of five blotches on the dorsum, flanks and dorsal fin. OPA generally were not associated with pre-existing skin traumas or scars (Table 2) and covered ca. 5-10\% of VBS. Some smaller blotches coalesced to form larger ones. With none of the dolphins re-sighted, progress could not be evaluated. The three cases occurred in winter (June and July).

\section{Cutaneous nodules}

Several medium to large NOD were observed on the dorsum and flanks of a solitary adult male killer whale freeranging in the coastal waters of northern Paraná $\left(25^{\circ} 20^{\prime} \mathrm{S}\right.$, $\left.45^{\circ} 05^{\prime} \mathrm{W}\right)$, southern Brazil, in March 2005. NOD were still present when this specimen was photographed off Praia de Maresias, São Paulo (2348’ S, 4523'W) in January 2007 (Fig. 3, Lodi and Farias-Junior, 2011), southeastern Brazil. The killer whale was seen again repeatedly in 2008-2010 along the coasts of São Paulo and Rio de Janeiro states (Lodi and FariasJúnior, 2011). Though image resolution was insufficient for

${ }^{7}$ E. Secchi, pers. comm. to MFB, 17 November 2009

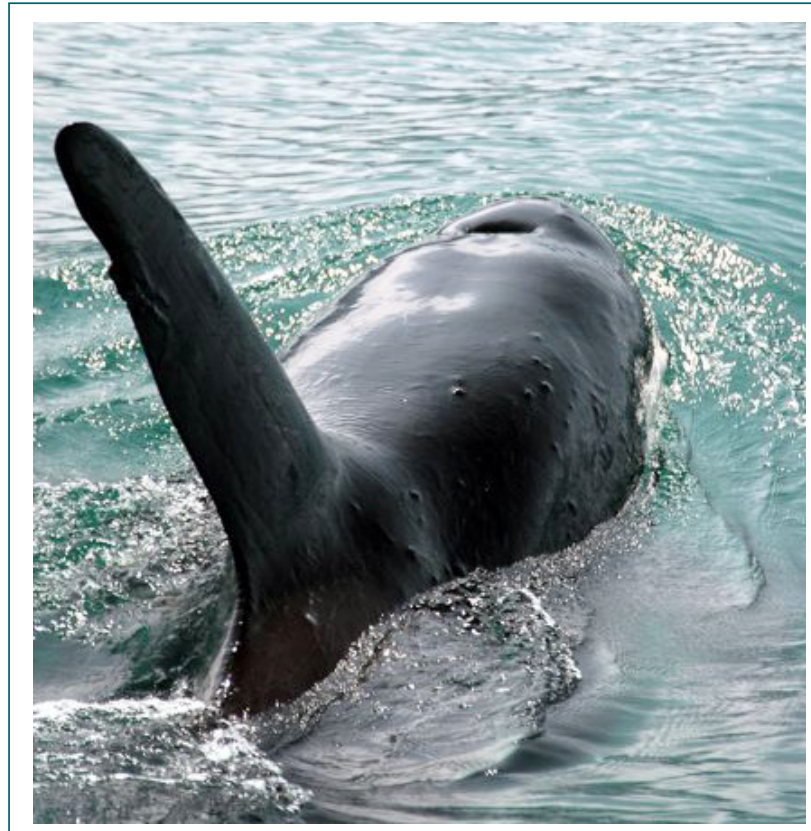

Figure 3. Cutaneous nodules in a male killer whale Orcinus orca off Praia de Maresias, São Paulo, January 2007.

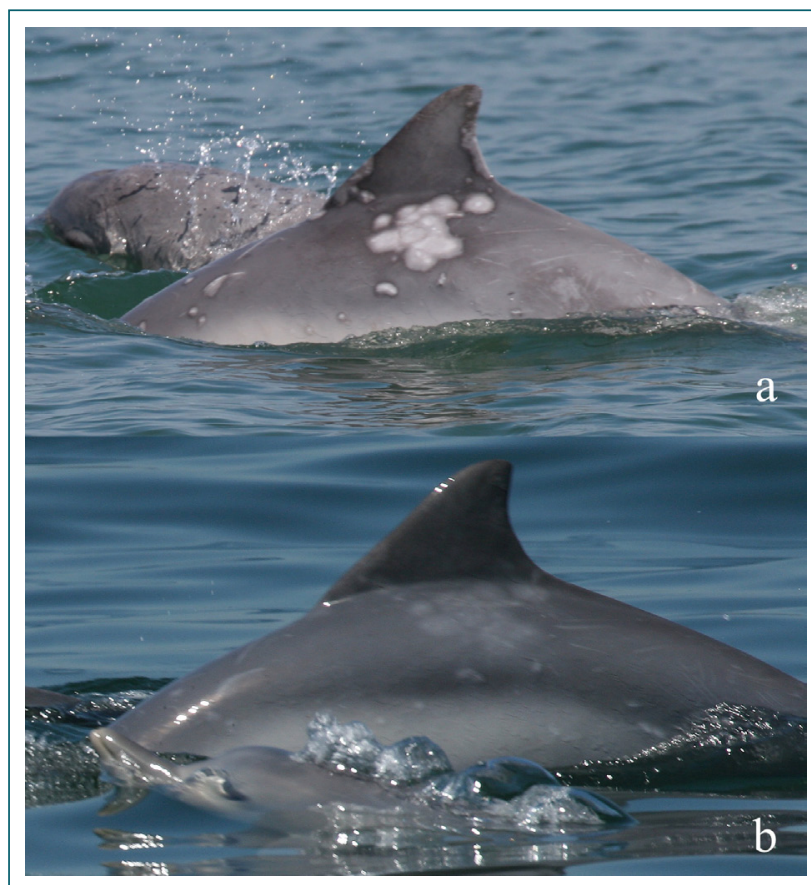

Figure 4. (a) Acute pale dermatitis in Guiana dolphin Sotalia guianensis SEP-41 from Sepetiba Bay on 28 October 2007; (b) Convalescent stage of pale dermatitis in SEP-41 on 4 March 2008.

skin disease assessment, the condition evidently had not been lethal in this five-year period.

\section{Pale dermititis}

Acute PAD lesions ranged in colour from off-white to light grey, and could affect as much as $35-40 \%$ of VBS, specifically on the dorsum, dorsal fin, flanks, flukes and rostrum (Fig. 4a; 


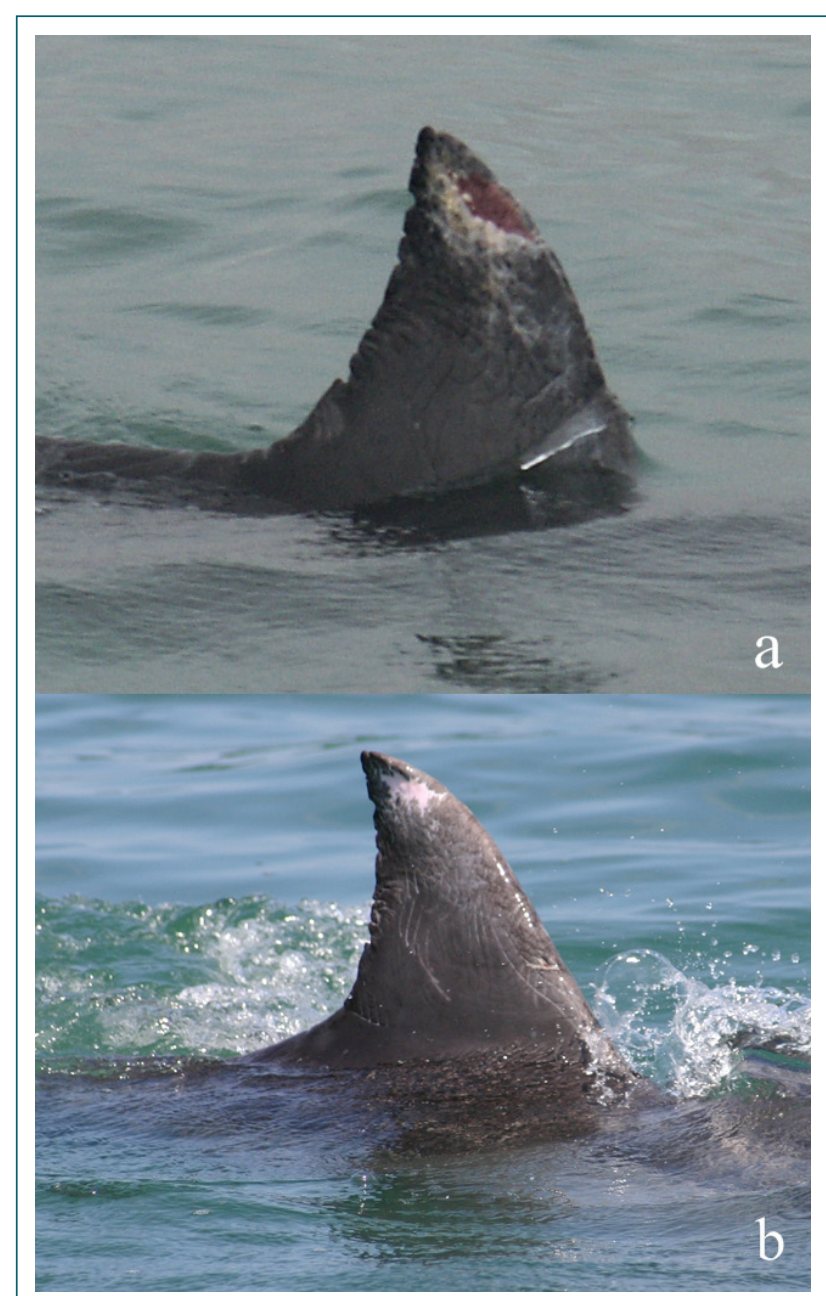

Figure 5. (a) Acute, ulcerated pale dermatitis in bottlenose dolphin Tursiops truncatus PBD-15 from Paracas Bay on 10 November 2004. (b) Healed pale dermatitis in PBD-15 on 18 January 2005.

Table 2). When clinical features of the disease regressed, the epidermis gradually re-pigmented, the lesions lost their raised and velvety aspect, and skin ulcers resolved. Although normal pigmentation eventually returned, light-grey blotches remained visible in some animals. When present in a population, prevalence of the disorder varied from $1-6.9 \%$.

\section{Case study 1: Sepetiba Bay}

Minimum population prevalence of acute PAD was 2.3\% in 222 Guiana dolphins from Sepetiba Bay, in 2005-2008. All affected dolphins were adults. Specifically, prevalence was 1.4\% in 209 free-ranging dolphins, $20 \%$ in 10 by-caught specimens and null in three stranded specimens (Table 1). In live dolphins SEP-33 and SEP-41 the lesions had a velvety aspect (Fig. 4a). In SEP-33 PAD was associated with a deep incision scar in front of the dorsal fin, possibly inflicted by fishing gear (Van Bressem et al., 2007), and with toothrakes on the left flank. First observed in July 2005, the lesions faded over a six-month period and light-grey blotches were all that remained in January 2006. In SEP-41, the sores were first seen in October 2007 and

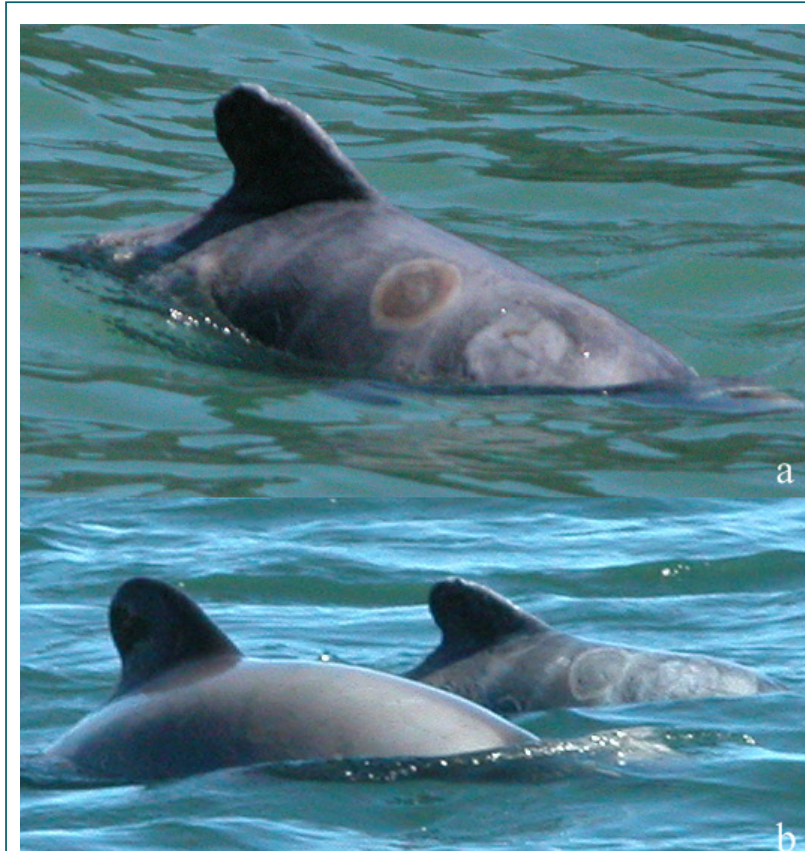

Figure 6. (a) Expansive annular lesions in a Chilean dolphin calf Cephalorhynchus eutropia from the Northern Fjords, Chile, on 13 February 2003; (b) the lesions have expanded and coalesced by 20 February 2003.

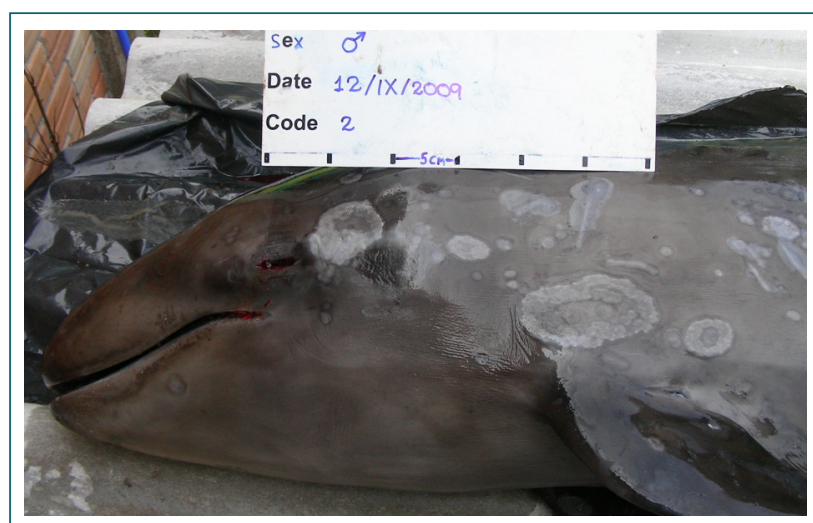

Figure 7. Expansive annular lesions in a false killer whale calf Pseudorca crassidens from Southern Brazil on 12 September 2009.

were mainly associated with scars. Though severe (Fig. 4a) they resolved in 4.5 months leaving only greyish blemishes (Fig. 4b). Recrudescence of acute PAD was not observed. PAD lesions on the lower jaw and gape in mature males SEP-17, SEP-24 and SEP-3 were also associated with minor injuries and scars (Table 2). In Sepetiba Guiana dolphins, pale dermatitis affected an estimated $1-40 \%$ of VBS. Healing skin lesions, possibly PAD, were present on the rostrum, dorsal fin and dorsum of four other free-ranging Guiana dolphins (Table 2).

\section{Case study 2: Paranaguá Estuary}

In the Paranaguá Estuary $\left(25^{\circ} 22^{\prime} \mathrm{S}, 48^{\circ} 25^{\prime} \mathrm{W}\right)$, Paraná state, southern Brazil, PAD prevalence was $1 \%$ in 103 Guiana dolphins in 2006-2008. Likely-regressing PAD, not associated with skin traumas, affected some $10 \%$ of VBS in a free-ranging 
adult Guiana dolphin in March 2007. The dermatitis had completely healed by early August 2007.

\section{Case study 3: Paracas Bay}

Acute PAD struck $6.9 \%$ of 87 photo-identified inshore bottlenose dolphins in the Paracas Bay (Paracas National Reserve, $\left.13^{\circ} 49^{\prime} \mathrm{S}, 76^{\circ} 16^{\prime} \mathrm{W}\right)$, south-central Peru, in 2004-2009 (Table 1). Five cases occurred during winter months (JuneAugust) and the sixth case also recurred in July (Table 2). The reason for this apparent seasonality is unknown. In all acutely affected dolphins PAD lesions covered $c a$. 3-20\% of VBS, were sometimes ulcerated and associated with toothrakes and other minor skin lacerations. The epidermis of the dorsal fin of two dolphins (PBD-15 and PBD-29) was ulcerated when first observed, exposing the dermis (Fig. 5a). The skin subsequently healed over a period of, respectively, two and six months, in 2004-2005 (Fig. 5b), leaving a white scar in PBD-15 and lightgrey marks in PBD-29. A milder recrudescence was noted in PBD-15 in July 2007. The lesions had healed again by July 2008 and no further dermatitis was observed in 2009. The velvety sores detected in July 2006 in PBD-55 had partially regressed by February 2008. Light grey marks surrounded linear incisive injuries on the dorsum of dolphins PBD-41 (June 2009) and PBD-78 (August 2009). Transient in the bay, female PBD-60 had severe PAD lesions on the dorsum and flanks in July 2006, after which she was not seen again. White scars evoking healed PAD were also present on the dorsal fin of PBD-030 in August 2005. With the exception of one old female without skin condition, no inshore bottlenose dolphins were found stranded during beach surveys in the Paracas Bay area in 2004-2009. Notably, no skin conditions were observed in 1999-2004 among a group of 15 inshore bottlenose dolphins resident in Supay-Arquillo (Table 1), a less-contaminated area on the south coast of the Paracas Peninsula, shielded from anthropogenic influences. Furthermore, acute PAD was not detected in 84 closely examined, freshly dead bottlenose dolphins of both inshore and offshore populations (sensu Van Waerebeek et al., 1990) taken in fisheries off central Peru in 1985-1995 (Table 1).

\section{Case study 4: Chanduy}

An adult male false killer whale of a group of about 60 individuals that stranded at Chanduy $\left(02^{\circ} 25^{\prime} \mathrm{S}, 80^{\circ} 40^{\prime} \mathrm{W}\right)$, Santa Elena Peninsula, Ecuador, in November 1992 had large, pale, PAD-type velvety marks affecting approximately $20 \%$ of the flukes. One of them, located on the anterior border of the left fluke, measured 450x110mm and was associated with a fresh wound. Prevalence was $3.6 \%$ for 28 examined carcasses.

\section{Expansive annular skin lesions}

Case study 1: Reñihue Fjord

An estimated one month old Chilean dolphin calf at Reñihue Fjord (42³4'S, 72³0'W), Palena Province, Chile, had large EAL on the dorsum flanks and head on 11 February
2003. The core lesion had an orange tinge and was surrounded by a light grey ring. Another lesion seemed ulcerated. By 13 February, the calf's EAL condition had progressed, i.e. the core lesion on its right flank had increased in diameter and became erythematous, while new blemishes were visible on both flanks, dorsum and head (Fig. 6a). Medium-sized grayish and ulcerative sores also affected the dorsal fin of the accompanying resident female CE065, presumably the mother. Over the next few days new sores kept emerging in the calf, existing ones expanded and merged, then turned light grey (Fig. 6b). The calf was last seen on 24 February with an estimated 30$40 \%$ of the VBS affected. During the 14 days of observation it struggled to breathe and swim. Female CE065 was repeatedly re-sighted alone in March and April 2003 and, presumably, the calf had died. Prevalence of the disease in 15 Chilean dolphins from Reñihue Fjord was 6.7\% in 2002-2004. Though TSD was present in this population at that time (Van Bressem et al., $2009 b$ ), no typical tattoo lesions were detected in the calf or its mother.

\section{Case study 2: Rio Grande do Sul}

A male false killer whale calf washed ashore dead in Rio Grande do Sul, Brazil, in September $2009^{7}$ with numerous, small to large, light grey EALs disseminated over its body (Fig. 7). Some lesions were associated with pre-existing linear scars and covered $c a .15 \%$ of the left side. It is suspected that the calf death was related to the cutaneous condition. Skin samples were collected in $10 \%$ formaldehyde and await analysis.

\section{Discussion}

With one exception, none of the observed cutaneous conditions could be biopsied or otherwise sampled and their aetiology remains unknown. However, the fact that phenotypically recognizable clinical symptoms occurred in photo-identified individuals, allowing assessment of disease progression and survival of several dolphins, deserved their documentation. Photographic examination has proven useful to classify skin disorders and study their epidemiological features in cetaceans worldwide (Wilson et al., 1997; 1999; Van Bressem et al., 2003; 2009b, c; 2013; Maldini et al., 2010; Daura-Jorge and Simóes-Lopes, 2011; Bertulli et al., 2012). Time series of the affected VBS fraction provides a safe and practical tool for monitoring the evolution and severity of skin conditions (Van Bressem et al., 2003; Murdoch et al., 2008; Kiszka et al., 2009; Riggin and Maldini, 2010; Daura-Jorge and Simóes-Lopes, 2011; this paper). Nevertheless, collection of samples from freshly dead animals is urgently needed to investigate the aetiologies of cutaneous disorders. Biopsy sampling with invasive techniques such as darts delivered by crossbows should however be carefully evaluated on a case-bycase base for the risk that a cutaneous pathogen may become inoculated in underlying tissues or even the bloodstream, apart from the inevitable harassment of chasing potentially weakened animals. 
During this study green-brown plaques were observed only in a pair of Guiana dolphins in a freshwater area of the Cananéia Estuary on 27 August 2009. GBP were not seen in 20 Guiana dolphins swimming in a slightly more saline (4ppt) part of the estuary on the same day. However, a very similar disorder to GBP was recognized from photographs of seven bottlenose dolphins trapped in Lake Pontchartrain, southeastern Louisiana, USA, in April-May 2008, and also exposed to a hypo-saline environment (salinities, 1-3ppt; Barry et al., 2008). We suggest that fresh or very low salinity waters may facilitate, or even trigger, the development of GBPlike syndrome in marine odontocetes. The prognosis of GBP affected dolphins is unclear.

Present cases of orange patches are highly reminiscent of epidermal diatoms in Dall's porpoises Phocoenoides dalli and harbour porpoises Phocoena phocoena in the North Pacific (Holmes et al., 1993; Norman et al., 2004). The pathogenic significance of diatoms is limited (Norman et al., 2004), if not nihil. Guiana dolphins with OPA were only observed during the winter in Sepetiba Bay, when mean sea surface temperature was $23.9^{\circ} \mathrm{C}$ (Flach et al., 2008). We suggest that 'orange film' and 'orange hue', 'orange patches' described in bottlenose dolphins from, respectively, the British Isles (Wilson et al., 1997) and California (Maldini et al., 2010) are equivalent to our OPA. Diatoms have long been reported from blue Balaenoptera musculus and fin B. physalus whales in the Southern Ocean (Bennett, 1920), as well as from sperm whales Physeter macrocephalus off South Africa (Best, 1969).

The cutaneous nodules seen in the single killer whale persisted at least 21 months. A nodular skin disease resembling lobomycosis was observed in 2006-2007 in 14 Guiana dolphins from the Paranaguá Estuary, close to the Cananéia Estuary (Van Bressem et al., 2009c). However, clinical manifestations were different i.e. raised, grey, orange or reddish, sometimes ulcerated, skin lumps (Van Bressem et al., 2009c). Cutaneous nodules unrelated to lobomycosis were reported in free-ranging Indo-Pacific bottlenose dolphins Tursiops aduncus from Japan, in Irrawaddy dolphins Orcaella brevirostris from Malaysia, India and Bangladesh, and in common minke whales Balaenoptera acutorostrata and a white-beaked dolphin Lagenorhynchus albirostris from Icelandic waters (Bertulli et al., 2012; Van Bressem et al., 2013; 2014). Though likely infectious their aetiology is still unknown.

Acute pale dermatitis appears consistent with 'white lesions', 'cream lesions' and 'white fin-fringe lesions' described from bottlenose dolphins in Scotland (Wilson et al., 1997) and perhaps the 'white lesions' in North Atlantic right whales Eubalaena glacialis (Hamilton and Marx, 2005). Creamy-white lesions on dorsum and dorsal fin, most likely PAD, were also reported in 1999 from more than a third of $c a .120$ bottlenose dolphins resident in the Gambia River estuary, West Africa. A large part of this community abandoned the estuary for several months and apparently moved towards open sea, thus impacting local dolphin-watching operations. When dolphins returned to the estuary, skin lesions had cleared ${ }^{8}$. In the present study PAD was encountered in three delphinid species in tropical and subtropical waters from South America. Although some cases appeared severe, prognosis was good with most affected dolphins partially or entirely clearing symptoms over a six-month period. Recrudescence occurred in at least one specimen. PAD seems to be a chronic, self-limiting infectious disorder for which there is no evidence of associated mortality, although overall fitness may be reduced to some degree. We suggest that toothrakes and other minor underlying skin traumas may offer routes of entry for superinfecting pathogens. Of 11 animals with active PAD in Peru and Brazil, eight were seen in winter (June-August) and a ninth case, first diagnosed in November 2004, regressed in summer (January 2005) but was recrudescent in winter (July 2007). Low sea surface temperature may be a predisposing factor.

Macroscopically, EAL were reminiscent of the cutaneous sores observed in a bottlenose dolphin calf from the Sado Estuary, Portugal (Van Bressem et al., 2003), a bottlenose dolphin calf from Monterey Bay, California (Riggin and Maldini, 2010) and a Commerson's dolphin Cephalorhynchus commersonii from Argentinean Patagonia (Van Bressem et al., 2007). In the calf from the Sado Estuary where TSD was highly prevalent, the lesions were believed to be superinfected tattoos (Van Bressem et al., 2003). Poxvirus-induced tattoo lesions were also thought to have facilitated the entry of fungi and bacteria in an Atlantic white-sided dolphin Lagenorhynchus acutus and a pygmy sperm whale Kogia breviceps stranded on the US Atlantic coast in 1991 and diagnosed with mycotic dermatitis (Frasca et al., 1996). In South America, EAL were detected only in cetacean populations in cool and temperate waters, although populations in lower latitudes were also under scrutiny (Van Bressem et al., 2007). Besides, a similar condition was recognized in a humpback whale Megaptera novaeangliae photographed in Admiralty Bay (62 $12^{\circ}$ 'S, $\left.058^{\circ} 25^{\prime} \mathrm{W}\right)$, King George Island, in the summer of $1994^{9}$. EAL may constitute a potentially severe, even lethal, cetacean disease. Of two affected calves, one was found dead with disseminated EAL lesions and the other in morbid condition disappeared and almost certainly died within two weeks after the condition was first diagnosed.

With the exception of two presumably oceanic false killer whales, all PAD and EAL-affected cetaceans inhabited biologically and chemically degraded nearshore waters. The community of inshore bottlenose dolphins studied in Peru ranges in a coastal strip between Paracas Bay and Tambo de Mora which is often heavily affected by raw sewage from surrounding towns (El Chaco, San Andrés, Pisco) and vast quantities of organic material released by fish-meal factories,

${ }^{8}$ Van Waerebeek, K., Barnett, L., Camara, A., Cham, A., Diallo, M., Djiba, A., Jallow, A.O., Ndiaye, E., Samba Ould Bilal, A.O. and Bamy, I.L. (2003) Conservation of cetaceans in the Gambia and Senegal 1999-2001, and status of the Atlantic humpback dolphin. WAFCET-2 Report, UNEP/ CMS, Bonn, Germany. 55 pp.

${ }^{9}$ E. Secchi, pers. comm. to MFB, 15 February 1996 
resulting in severe eutrophication ${ }^{10}$. The factories also release effluent with caustic soda when cleaning machinery ${ }^{11}$. In addition, ballast water from cargo ships entering Paracas Bay to dock at the Camisea Liquefied Natural Gas (LNG) platform or San Martín harbour may introduce alien, potentially dangerous, micro-organisms ${ }^{10}$ (Ruiz et al., 2000; Drake et al., 2007). Coastal development including new beach-front hotels and other tourist facilities along the shores of the Paracas Bay, the expansion of the LNG plant and increasing ship traffic represent accumulating challenges to the inshore bottlenose dolphin communities of Ica department. Brazil's Paranaguá Estuary also has a large port, surrounded by expanding urbanization. An illegal shrimp farm operated in 2006-2007 (M. Santos, pers. obs) and may have adversely affected the Paranaguá Estuary habitat. Home to two large ports, Sepetiba Bay suffers chemical and organic aquatic pollution and eutrophication (Copeland et al., 2003; Molisani et al., 2004). Chile's Reñihue Fjord was home to three open-net salmon farms which heavily consumed prophylactic antibiotics and released biological and chemical contaminants directly into the ocean in 2003-2004 (Cabello, 2004; 2006). The two cases of EAL and PAD in false killer whales occurred off the coasts of heavily polluted regions. Although banned in much of the Northern Hemisphere since the 1970s due to their high toxicity to humans and wildlife, several organochlorine compounds are still widely used in South America ${ }^{12}$. In Rio Grande do Sul, one of the most industrially developed regions of southern Brazil, organochlorine pesticides supporting high agricultural production have long entered the southwest Atlantic ecosystems (Marsili, 2000). Salinas, in Ecuador's Santa Elena Province, features a major yacht marina, a large fishing port for artisanal and industrial vessels as well as a port for petroleum tankers, leading to heavy maritime traffic. The adjacent coast boasts a string of densely-populated seaside resorts and is characterized by high levels of microbiological and chemical pollution ${ }^{13}$. Intense shrimp-farming and fishing plants in this area also produce large quantities of sludge and organic material ${ }^{14}$.

The exponential increase in reports of, often severe, skin disorders in cetaceans worldwide (Van Bressem et al., 1993; 2007; 2009c; 2013; Wilson et al., 1999; Reif et al., 2006; Barry et al., 2008; Maldini et al., 2010; Riggin and Maldini, 2010; Daura-Jorge and Simóes-Lopes, 2011; Bertulli et al., 2012; Fury

\footnotetext{
${ }^{10}$ PNUMA/CONAM (2006) Informe sobre el Estado del Medio Ambiente. GEO Bahía Paracas-Pisco. Lima, Peru. 164 pp.

${ }^{11}$ CPPS, Comisión Permanente del Pacífico Sur (1988) Estudio piloto para el ordenamiento ambiental del área Pisco Paracas (Ica, Peru), Volumen I: Diagnóstico Ambiental del área de Pisco Paracas. Lima, Peru. 331 pp. ${ }^{12}$ PNUMA (2002) Evaluación regional sobre sustancias tóxicas persistentes. Informe regional de Sudamérica oriental y occidental. Programa de Las Naciones Unidas para el Medio Ambiente, UNEP, Switzerland. ${ }^{13}$ DIGEIM, Dirección de Intereses Marítimos de la Armada de Ecuador (2007) Informe final del proyecto piloto 'Fundamentos para el control de la contaminación en el puerto pesquero de Santa Rosa y su área de influencia', Ecuador (unpublished).

${ }^{14}$ WRM, World Rainforest Movement (2001) Unsustainable versus sustainable shrimp production. WRM Bulletin 51, October 2001. Available at http://www.wrm.org.uy/bulletin/51/production.html. Consulted on 20 September 2013.
}

and Reif, 2012) cannot alone be explained by intensified field research, and suggests a causal link with markedly deteriorating coastal environments. Climate change may also play a role in the emergence of skin diseases by increasing pathogen survival through higher water temperatures and by changing pathogen and host interaction dynamics (Burek et al., 2008). Mounting levels of solar ultraviolet radiation may further favour the development of cutaneous diseases by inducing DNA damage in the epidermis (Bowman et al., 2013).

We conclude that at least two (EAL and PAD) of the five skin conditions described here may be associated with, and indicative of, a compromised nearshore environment. Their emergence in small populations of vulnerable odontocetes is of particular concern and should be closely monitored.

\section{Acknowledgments}

We thank Dr E. Secchi for kindly providing unpublished data on a humpback whale and a false killer whale. We kindly acknowledge three anonymous referees for their thorough review of the manuscript and for offering useful comments. ACOREMA received support from Gesellschaft zur Rettung der Delphine (GRD-Germany) and Cetacean Society International. Dolphin research in the Paracas National Reserve was carried out under permits issued by the Instituto Nacional de Recursos Naturales (INRENA), Peru. The work of L. Flach and M. Santos was supported, respectively by Companhia Vale do Rio Doce and by Fundação de Amparo à Pesquisa do Estado de São Paulo. Van Waerebeek attended the $60^{\text {th }}$ meeting of the International Whaling Commission, where preliminary results were presented, as head of scientific delegation for the Federal Public Service, Public health, Food Chain Security and Environment, Brussels, Belgium. This paper is dedicated to the memory of IWC Commissioner (Belgium) Alexandre de Lichtervelde who passed away in 2011. AdL energetically encouraged marine environmental research.

\section{References}

Bennett, A. (1920) On the occurrence of diatoms on the skin of whales. Proceedings of the Royal Society of London, Series B 91: 352-357. http://dx.doi.org/10.1098/rspb.1920.0021

Bermudez, L., Van Bressem, M-F., Reyes-Jaimes, O., Sayegh, A.J. and Paniz-Mondolfi, A.E. (2009) Lobomycosis in man and lobomycosis-like disease in bottlenose dolphin, Venezuela. Emerging Infectious Diseases 15(8): 1301-1303. http://dx.doi.org/10.3201/eid1508.090347

Bertulli, C.G., Cecchetti, A., Van Bressem, M-F. and Van Waerebeek, K. (2012) Skin disorders in common minke whales and white-beaked dolphins off Iceland, a photographic assessment. Journal of Marine Animals and their Ecology 5: 29-40.

Best, P.B. (1969) The sperm whale (Physeter catodon) off the west coast of South Africa, 4, Distribution and movements. Investigational Reports Division of Sea Fisheries of South Africa 78: $1-12$. 
Bowman, A., Martinez-Levasseus, L.M., Acevedo-Whitehouse, K., Gendron, D. and Birch-Machin, M.A. (2013) The simultaneous detection of mitochondrial DNA damage from sun-exposed skin of three whale species and its association with UV-induced microscopic lesions and apoptosis. Mitochondrion 13: 342-349. http://dx.doi.org/10.1016/j.mito.2013.04.003

Burek, K.A., Gulland, F.M. and O'Hara, T.M. (2008) Effects of climate change on Arctic marine mammal health. Ecological Applications 18: S126-S134. http://dx.doi.org/10.1890/06-0553.1

Cabello, F.C. (2004) Antibioticos y acuicultura en Chile: consecuencias para la salud humana y animal. Revista de Medicina de Chile 132: 1001-1006.

http://dx.doi.org/10.4067/S0034-98872004000800014

Cabello, F.C. (2006) Heavy use of prophylactic antibiotics in aquaculture: a growing problem for human and animal health and for the environment. Environmental Microbiology 8: 11371144. http://dx.doi.org/10.1111/j.1462-2920.2006.01054.x

Copeland, G., Monteiro, T., Couch, S. and Borthwick, A. (2003) Water quality in Sepetiba Bay, Brazil. Marine Environment Research 5: 385-408. http://dx.doi.org/10.1016/ S0141-1136(02)00289-1

Culik, B.M. (2004). Review of small cetaceans. Distribution, behaviour, migration and threats. Wurtz, M. (Ed.) UNEP-CMS. Regional Seas Reports and Studies 177. 343 pp.

Daura-Jorge, F.G. and Simôes-Lopes, P.C. (2011) Lobomycosislike disease in wild bottlenose dolphins Tursiops truncatus of Laguna, southern Brazil: monitoring of a progressive case. Diseases of Aquatic Organisms 93: 163-170.

http://dx.doi.org/10.3354/dao02291

De Vries, G.A. and Laarman, J.J. (1973) A case of Lobo's disease in the dolphin Sotalia guianensis. Aquatic Mammals 1: 26-33.

Drake, L., Doblin, M.A. and Dobbs, F.C. (2007) Potential microbial bioinvasions via ships' ballast water, sediment, and biofilm. Marine Pollution Bulletin 55: 333-341. http://dx.doi.org/10.1016/j.marpolbul.2006.11.007

Durban, J.W. and Parsons, K.W. (2006) Laser metrics of freeranging killer whales. Marine Mammal Science 22: 735-743. http://dx.doi.org/10.1111/j.1748-7692.2006.00068.x

Esperón, F., García-Párraga, D., Bellière, E.N. and SánchezVizcaíno, J.M. (2012) Molecular diagnosis of lobomycosis-like disease in a bottlenose dolphin in captivity. Medical Mycology 50: 106-109.

Félix, F. (1992) Varamiento masivo de falsas orcas en Chanduy. El Observador Informativo de la Fundación Ecuatoriana para el Estudio de Mamíferos Marinos 4:1-2.

Fish, F.E. (1998) Comparative kinematics and hydroynamics of odontocete cetaceans: morphological and ecological correlates with swimming perfomances. The Journal of Experimental Biology 201: 2867-2877.
Flach, L., Flach, P.A. and Chiarello, A.G. (2008) Aspects of behavioural ecology of Sotalia guianensis in Sepetiba Bay, southeast Brazil. Marine Mammal Science 24: 503-515. http://dx.doi.org/10.1111/j.1748-7692.2008.00198.x

Frasca, S. Jr, Dunn, J.L., Cooke, J.C. and Buck, J.D. (1996) Mycotic dermatitis in an Atlantic white-sided dolphin, a pygmy sperm whale, and two harbour seals. Journal of the American Veterinary Medical Association 208: 727-729.

Fury, C.A. and Reif, J.S. (2012) Incidence of poxvirus-like lesions in two estuarine dolphin populations in Australia: links to flood events. Science of the Total Environment 416: 536-540. http://dx.doi.org/10.1016/j.scitotenv.2011.11.056

Hamilton, P.K. and Marx, M.K. (2005) Skin lesions on North Atlantic right whales: categories, prevalence and change in occurrence in the 1990s. Diseases of Aquatic Organisms 68: 71-82. http://dx.doi.org/10.3354/dao068071

Haubold, E.M., Cooper Jr, C.R., Wen, J.W., McGinnis, M.R. and Cowan, D.F. (2000) Comparative morphology of Lacazia loboi (syn. Loboa loboi) in dolphins and humans. Medical Mycology 38: 9-14.

Holmes, R.W., Nagasawa, S. and Takano, H. (1993) The morphology and geographic distribution of epidermal diatoms of the Dall's porpoise (Phocoenoides dalli) in the northern Pacific Ocean. Bulletin National Science Museum, Tokyo, Series B 19: 1-18.

Izidoro, B.F. and Le Pendu, Y. (2012) Estuarine dolphins (Sotalia guianensis) (Van Bénéden, 1864) (Cetacea: Delphinidae) in Porto de Ilhéus, Brazil: group characterisation and response to ships. North-Western Journal of Zoology 8(2): 232-240.

Kiszka, J., Van Bressem, M-F. and Pusineri, C. (2009) Lobomycosis-like disease and other skin conditions in IndoPacific bottlenose dolphins Tursiops aduncus from the Indian Ocean. Diseases of Aquatic Organisms 84:151-157.

http://dx.doi.org/10.3354/dao02037

Lodi, L. and Farias-Júnior, S. (2011) Movements of a solitary adult male killer whale, Orcinus orca (Cetacea, Delphinidae), along the coast of south-eastern Brazil. Pan American Journal of Aquatic Sciences 6: 325-328.

Maldini, D., Riggin, J., Cecchetti, A. and Cotter, M.P. (2010) Prevalence of epidermal conditions in California coastal bottlenose dolphins (Tursiops truncatus) in Monterey Bay. Ambio 39: 455-462. http://dx.doi.org/10.1007/s13280-0100066-8

Marsili, L. (2000) Lipophilic contaminants in marine mammals: review of the results of ten years' work at the Department of Environmental Biology, Siena University (Italy). International Journal of Environmental Pollution 13: 416-452. http://dx.doi.org/10.1504/IJEP.2000.002329 
Molisani, M.M., Marins, R.V., Machado, W., Paraquetti, H.H.M., Bidone, E.D. and Lacerda, L.D. (2004) Environmental changes in Sepetiba Bay, SE Brazil. Regional Environmental Changes 4: 17-27.

Murdoch, M.E., Reif, J.S., Mazzoil, M., McCulloch, S.D., Fair, P.A. and Bossart, G.D. (2008) Lobomycosis in bottlenose dolphins (Tursiops truncatus) from the Indian River Lagoon, Florida: estimation of prevalence, temporal trends, and spatial distribution. EcoHealth 5: 289-297.

http://dx.doi.org/10.1007/s10393-008-0187-8

Norman, S.A., Raverty, S., McLellan, B., Pabst, A., Ketten, D., Fleetwood, M., Gaydon, J.K., Norberg, B., Barre, L., Cox, T., Hanson, B. and Jeffries, S. (2004) Multidisciplinary investigation of stranded harbor porpoises (Phocoena phocoena) in Washington State with an assessment of acoustic trauma as a contributory factor (2 May-2 June 2003). US Department of Commerce, NOAA Technical Memorandum NMFS-NWR-34. 120 pp.

Reif, J.S., Mazzoil, M.S., McCullogh, S.D., Varela, R., Goldstein, J.D., Fair, P. and Bossart, G.D. (2006) Lobomycosis in Atlantic bottlenose dolphins from the Indian River Lagoon, Florida. Journal of the American Veterinary Medical Association 228: 104-108. http://dx.doi.org/10.2460/javma.228.1.104

Reif, J.S., Peden-Adamns, M.M., Romano, T.A., Rice, C.D., Fair, P.A. and Bossart, G.D. (2009) Immune dysfunction in Atlantic bottlenose dolphins (Tursiops truncatus) with lobomycosis. Medical Mycology 47:125-135.

http://dx.doi.org/10.1080/13693780802178493

Reyes, J.C., Echegaray, M. and De Paz, N. (2002) Distribución, comportamiento y conservación de cetáceos en el área Pisco Paracas. Pages 136-144 in Mendo, J. and Wolff, M. (Eds) Memorias I Jornada Cientifica Reserva Nacional de Paracas. Universidad Nacional Agraria, Lima, Peru.

Riggin, J. and Maldini, D. (2010) Photographic case studies of skin conditions in wild-ranging bottlenose dolphin (Tursiops truncatus) calves. Journal of Marine Animals and their Ecology 3: 5-9.

Rotstein, D.S., Burdett, L.G., McLellan, W., Schwacke, L., Rowles, T., Terio, K.A., Schultz, S. and Pabst, A. (2009) Lobomycosis in offshore bottlenose dolphins (Tursiops truncatus), North Carolina. Emerging Infectious Diseases 15: 588-590.

Ruiz, G.M., Rawlings, T.K., Dobbs, F.C., Drake, L.A., Mullady, T., Huq, A. and Colwell, R.R. (2000) Global spread of microorganisms by ships. Nature 408: 49-50.

http://dx.doi.org/10.1038/35040695

Santos, M.C.O. and Netto, D.F. (2005) Killer whale (Orcinus orca) predation on franciscana dolphin (Pontoporia blainvillei) in Brazilian waters. Latin American Journal of Aquatic Mammals 4: 69-72. http://dx.doi.org/10.5597/lajam00072
Santos, M.C.O. and Rosso, S. (2007) Ecological aspects of marine tucuxi dolphins (Sotalia guianensis) based on group size and composition in the Cananéia estuary, southeastern Brazil. Latin American Journal of Aquatic Mammals 6: 71-82. http://dx.doi.org/10.5597/lajam00110

Santos, M.C.O. and Rosso, S. (2008) Social organization of marine tucuxi dolphins, Sotalia guianensis, in the Cananéia estuary, southeastern Brazil. Journal of Mammalogy 88: 347-355.

Shane, S.H. (1990) Behavior and ecology of the bottlenose dolphin at Sanibel Island, Florida. Pages 245-265 in Leatherwood, S. and Reeves, R.R. (Eds) The Bottlenose Dolphin. Academic Press, San Diego, CA, USA

Simóes-Lopes, P.C., Paula, G.S., Xavier, F.M. and Scaramelo, A.C. (1993) First case of lobomycosis in bottlenose dolphin from Southern Brazil. Marine Mammal Science 9: 329-331. http://dx.doi.org/10.1111/j.1748-7692.1993.tb00462.x

Taborda, P.R., Taborda, V.A. and McGinnis, M.R. (1999) Lacazia loboi gen. nov., comb. nov., the aetiologic agent of lobomycosis. Journal of Clinical Microbiology 37: 2031-2033.

Ueda, K., Sano, A., Yamate, J., Nakagawa, E.I., Kuwamura, M., Izawa, T., Tanaka, M., Hasegawa, Y., Chibana, H., Izumisawa, Y., Miyahara, H. and Uchida, S. (2013). Two cases of lacaziosis in bottlenose dolphins (Tursiops truncatus) in Japan. Case Report Veterinary Medicine ID 318548, 9 pp.

Van Bressem, M-F., Van Waerebeek, K., Reyes, J-C., Dekegel, D. and Pastoret, P-P. (1993) Evidence of poxvirus in dusky dolphin (Lagenorhynchus obscurus) and Burmeister's porpoise (Phocoena spinipinnis) from coastal Peru. Journal of Wildlife Diseases 29: 109-113.

http://dx.doi.org/10.7589/0090-3558-29.1.109

Van Bressem, M-F., Van Waerebeek, K. and Raga, J.A. (1999) A review of virus infections of cetaceans and the potential impact of morbilliviruses, poxviruses and papillomaviruses on host population dynamics. Diseases of Aquatic Organisms 38:53-65. http://dx.doi.org/10.3354/dao038053

Van Bressem, M-F., Gaspar, R. and Aznar, J. (2003) Epidemiology of tattoo skin disease in bottlenose dolphins (Tursiops truncatus) from the Sado estuary, Portugal. Diseases of Aquatic Organisms 56: 171-179.

http://dx.doi.org/10.3354/dao056171

Van Bressem, M-F., Van Waerebeek, K., Reyes, J.C., Félix, F., Echegaray, M., Siciliano, S., Di Beneditto, A.P., Flach, L., Viddi, F., Avila, I.C., Herrera, J.C., Tobón, I.C., Bolaños, J., Moreno, I.B., Ott, P.H., Sanino, G.P., Castineira, E., Montes, D., Crespo, E., Flores, P.A.C., Haase, B., Mendonça de Souza, S.M.F., Laeta, M. and Fragoso, A.B. (2007) A preliminary overview of skin and skeletal diseases and traumata in small cetaceans from South American waters. Latin American Journal of Aquatic Mammals 6: 7-42.

http://dx.doi.org/10.5597/lajam00108 
Van Bressem, M-F., Raga, J.A., Di Guardo, G., Jepson, P.D., Duignan, P.J., Siebert, U., Barrett, T., Santos, M.C., Moreno, I.B., Siciliano, S., Aguilar, A. and Van Waerebeek, K. (2009a) Emerging infectious diseases in cetaceans worldwide and the possible role of environmental stressors. Diseases of Aquatic Organisms 83:143-157. http://dx.doi.org/10.3354/dao02101

Van Bressem, M-F., Van Waerebeek, K., Raga, J.A., Jepson, P.D., Duignan, P., Deaville, R., Flach, L., Viddi, F., Baker, J.R., Di Beneditto, A.P., Echegaray, M., Genov, T., Reyes, J.C., Felix, F., Gaspar, R., Ramos, R., Peddemors, V. and Siebert, U. (2009b) Epidemiological pattern of tattoo skin disease: a potential general health indicator for cetaceans. Diseases of Aquatic Organisms 85: 225-237.

http://dx.doi.org/10.3354/dao02080

Van Bressem, M-F., Santos, M.C.O. and Faria Oshima, J. (2009c) Skin diseases in Guiana dolphins (Sotalia guianensis) from the Paranaguá estuary, Brazil: A possible indicator of a compromised marine environment. Marine Environmental Research 67: 63-68.

http://dx.doi.org/10.1016/j.marenvres.2008.11.002

Van Bressem, M-F., Shirakihara, M. and Amano, M. (2013) Cutaneous nodular disease in a small population of IndoPacific bottlenose dolphins, Tursiops aduncus, from Japan. Marine Mammal Science 29: 525-532.

http://dx.doi.org/10.1111/j.1748-7692.2012.00589.x

Van Bressem, M-F., Minton, G., Sutaria, D., Kelkar, N., Peter, C., Zulkarnaen, M., Manzur, R.M., Porter, L., Vargas, L.H. and Rajamani, L. (2014) Cutaneous nodules in Irrawaddy dolphins: and emerging disease in vulnerable populations. Diseases of Aquatic Organisms 107: 181-189. http://dx.doi. org/10.3354/dao02689
Van Waerebeek, K., Reyes, J.C., Read, A.J. and KcKinnon, J.S. (1990) Preliminary observations of bottlenose dolphins from the Pacific coast of South America. Pages 143-154 in Leatherwood, S. and Reeves, R.R. (Eds) The Bottlenose Dolphin. Academic Press, San Diego, CA.

Wells, R.S., Irvine, A.B. and Scott, M.D. (1980) The social ecology of inshore odontocetes. Pages 263-317 in Herman, L.M. (Ed.) Cetacean behavior: Mechanisms and Functions. John Wiley and Sons, New York, USA.

Wilson, B., Thompson, P.M. and Hammond, P.S. (1997) Skin lesions and physical deformities in bottlenose dolphins in the Moray Firth: population prevalence and age-sex differences. Ambio 26: 243-247.

Wilson, B., Arnold, H., Bearzi, G., Fortuna, C.M., Gaspar, R., Ingram, S., Liret, C., Pribanic, S., Read, A.J., Ridoux, V., Schneider, K., Urian, K.W., Wells, R.S., Wood, C., Thompson, P.M. and Hammond, P.S. (1999) Epidermal lesions in bottlenose dolphins: impacts of natural and anthropogenic factors. Proceedings of the Royal Society of London, B 266:10771083. http://dx.doi.org/10.1098/rspb.1999.0746

Würsig, B. and Jefferson, R.A. (1990) Methods of photoidentification for small cetaceans. Reports of the International Whaling Commission (Special Issue) 12: 42-43. 